(ISSN - 2752-7018)

VOLUME 02 ISSUE 01 Pages: 69-78

SJIF IMPACT FACTOR (2021: $5 \cdot 376)$

OCLC - 1276789625 METADATA IF - 7.569

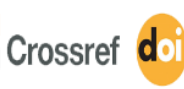

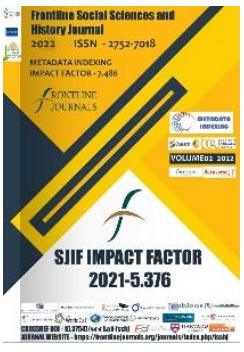

Journal Website: https://frontlinejournal s.org/journals/index.ph $\mathrm{p} /$ fsshj

Copyright: Original content from this work may be used under the terms of the creative commons attributes 4.0 licence.
Research Article

\section{AGE-RELATED FEATURES OF ENGLISH LANGUAGE TEACHING IN PRE-SCHOOL EDUCATIONAL INSTITUTIONS}

Submission Date: January 11, 2022, Accepted Date: January 20, 2022,

Published Date: January 31, 2022

Crossref doi: https://doi.org/10.37547/social-fsshj-02-01-09

Gulnora Nematovna Ergasheva

Researcher of Namangan State University, Uzbekistan

\title{
Abstract
}

There are a number of research studies were identified in which the age-related factors in foreign language teaching to young learners. This article discusses age-related features of teaching English in pre-school institutions based on scientific and methodological research studies and our observations.

\section{KeYwords}

Language learning, young learner, pre-school institution, age-periods, school age, scientific research studies.

\section{INTRODUCTION}

Language learning depends on age periods.

Psychologists note that children master a foreign language quickly and easily in comparison with adults. The main reasons of this natural tendency 
(ISSN - 2752-7018)

VOLUME 02 ISSUE 01 Pages: 69-78

SJIF IMPACT FACTOR (2021: 5 · 376)

OCLC - 1276789625 METADATA IF - 7.569

of children in terms of learning a language, in fact, they have a strong ability to imitate, and have more free time than adults. It should be noted that the child at age of 5-6 does not understand the meaning of words, however he/she approaches the words directly and can memorize them. Therefore, it is important not to start teaching grammar of a foreign language to children under school age. In this case, the child becomes tense and loses interest in learning the language. It is also necessary to take into account their age and psychological-individual characteristics when teaching a foreign language to young children. Teaching children foreign languages mainly involves practical goals such as increasing their vocabulary and teaching them to pronounce correctly. It is not secret that even preschool children are interested in learning foreign languages as their parents are also approaching this issue with great responsibility today. However, we do not have enough scientific and methodological research on teaching foreign languages, especially teaching English to young children. This creates difficulties in the acquisition of foreign languages by children. A number of studies have been conducted in this area in the experience of foreign countries. In particular, in recent years, it was noted the importance of integrating and teaching foreign languages in the conditions of kindergarten and primary school, teaching children not only practical goals, but also planning tasks focused on developing the child's thinking.

Although our country pays great attention to the study and teaching of foreign languages, the didactic principles of teaching foreign languages to preschool children are not fully developed. The topic of overcoming the problems in this regard and developing an effective methodology for teaching English to young children is still relevant. The use of poetry, songs, fairy tales, and riddles accelerates the process of developing the English vocabulary of preschool children, expanding their vocabulary and teaching them to speak. It consists of developing scientific and theoretical bases and effective methods of using poetry, songs, fairy tales, riddles in teaching preschool children to increase their vocabulary and speak English.

It is known that the research on foreign language teaching was formed in the history of pedagogy and psychology in the first half of the twentieth century. The first work "The Psychology of Foreign Language Learning" was published by an expert X. R. Hughes (1931) and his research was 
(ISSN - 2752-7018)

VOLUME 02 ISSUE 01 Pages: 69-78

SJIF IMPACT FACTOR (2021: 5 · 376)

OCLC - 1276789625 METADATA IF - 7.569

continued further by many scientists such as H.J. Dipkel, V. Rivers, Dj. Kerrol, R. Polittser, S. Donau, V. Moulton, L. Yakobovich, B. Reyneke, V. Appelt, I. V. Karpova, B. V. Belyaev, V. A. Artemov and other psychologists who emphasized psychology of youth should be considered in teaching a foreign language [1].

Also, research studies on the formation of oral language skills and abilities of preschool children (5-6 years old) in foreign languages [2], the formation of children's oral skills in Russian in Uzbek kindergartens through didactic games [3], scientific and methodological development of foreign language teaching in early education and critical learning were studied in scientific researches of the scholars such as N.N.Achkasova, O. M. Osiyanova, N. A. Malkina, O. A. Denisenko, B. Cheptsova [4] N. N. Achkasova, N. A. Yatsenko [5] and etc.

There are a number of research studies were identified in which the age-related factors in foreign language teaching were studied in the works including into the psychological approaches to the formation of communication skills in preschool educators [6], the basics of teaching foreign languages to preschool children [7], types of exercises used in teaching foreign languages to preschool children [8], methods of teaching foreign languages to preschool children [9], teaching foreign languages to preschool children through games [10], the use of English literature in teaching English [11], teaching communication to children aged 6-7 through storytelling roles [12] and the formation of oral speech using fairy tales for preschool children [13]. Features of teaching a foreign language to children from an early age through communicative orientation were studied by A.A. Leontev, V.G. Kostomarov, O.D. Mitrofanova [14] and et al. However, we can not say that there is enough research on the teaching of foreign languages, including English, to children in preschool education in our country. Therefore, in terms of this research study, we tried to analyze the role of adolescence in teaching English to preschool children on the basis of our observations and the views of world educators and psychologists' research studies listed above on foreign language teaching.

The question naturally arises "at what age is it best to teach a child a foreign language?" A number of studies have been conducted in this regard. For example, I.L.Sholpo, the author of the course "How can I teach children to speak 
(ISSN - 2752-7018)

VOLUME 02 ISSUE 01 Pages: 69-78

SJIF IMPACT FACTOR (2021: 5 · 376)

OCLC - 1276789625 METADATA IF - 7.569

English?" says that the most effective time is to start teaching a foreign language to children from the age of five. He claims, "of course, it is possible to teach four-year-olds, but it is ineffective" [15]. A scholar Z. Ya Futerman confirmed Sholpo's opinion through his research. In this experiment, two groups consisting of children at the age of four and five were participated. Younger group participants had some difficulty learning the language than five-year-old children. It was even known that this experience had a negative effect on the speech of young children. According to $\mathrm{Z}$. Ya. Futterman, a positive and quality period for learning a foreign language for children is at the age of five [16]. A. Arkin emphasizes that the age of five is the most appropriate period to start learning whereas children develop both physiologically and psychologically. Undoubtedly, the child's lexical vocabulary will increase and they will be able to communicate easily during this period. The expediency of using role-playing games has been stated at the age of four and five [17].

The best age to learn a foreign language at six was stated at an international conference organized by the European Committee. Psychologist A. A. Leontev also admits that exactly the age of six is the best time to learn a foreign language. According to Leontev, children will have a strong inner motivation and interest in a new language during this period, it is advisable to use this situation to teach children a foreign language through fun games. So, the best time to start teaching English to preschoolers is at 5-6.

What features of the age group are manifested in the process of teaching a foreign language to children of preschool age, and what is the appropriate approach to this process?

K.D. Ushinsky points out that a young child learns to speak a foreign language better in a few months in comparison of adults learn in years [18]. According to the scientist, learning a foreign language helps to achieve the following goals:

The first goal is that children learn the creativity of the target language.

The second goal is to expand the scope of logical thinking, as language learning has a positive effect on human brain activity and develops it in all respects.

The third goal is to get acquainted with the culture of these nations and be able to easily communicate with them. The next is to develop 
(ISSN - 2752-7018)

VOLUME 02 ISSUE 01 Pages: 69-78

SJIF IMPACT FACTOR (2021: 5 · 376)

OCLC - 1276789625 METADATA IF - 7.569

the ability to write letters with people from that foreign country in their own language.

According to L.S. Vygotsky, children begin to learn their mother tongue spontaneously, involuntarily, and consciously learn a foreign language. Therefore, language learning skills are formed in children as follows: the mother tongue develops from the bottom up, and the foreign language develops from the top down [19]. Thus, the child receives worldly knowledge through language.

I. A. Zimnyaya considers that children should learn a foreign language based on their mother tongue experiences in the educational process, only then it will be easier to memorize foreign words [20].

Professor N. A. Bonk claims that it is necessary to take into account psychology when teaching a young child a foreign language as the young learner is curious and does not like boredom. In this regard, it is advisable to use appropriate topics to kindergarten children including toys, animals, family, home, garden, and so on. The early learning process encourages preschool children to learn a foreign language in depth, allowing them to ensure fluency in their speech in the future [21].

Learning foreign languages from an early age does not practically improve the quality of speaking a foreign language, but provides a basis for perfect mastery of a foreign language in school and encourages for learning more languages in the future. Fairy tales are one of the most effective ways to teach a foreign language and demonstrate children's listening and speaking skills. According to research by L.S. Vygotskiy, A.V. Zaporozhets, V.S. Muxina, A.P. Usova et al., listening to fairy tales helps young learners at 5-6 ages will develop memory, attention, and imagination. Many experts say that fairy tales help children in preschools learn a foreign language. Accordingly, fairy tales introduce children to the culture of another world, acquaint them closely with the folklore of this country and create a positive environment for language learning [22]. The scholar V.S. Mukhina also notes that by listening to a fairy tale, words and phrases that are unfamiliar to children are easily assimilated and memory skills are enhanced [23]. We all know that games are the main type of activity of preschool children. Therefore, didactic games are 
(ISSN - 2752-7018)

VOLUME 02 ISSUE 01 Pages: 69-78

SJIF IMPACT FACTOR (2021: 5 · 376)

OCLC - 1276789625 METADATA IF - 7.569

widely used in preschool education as an educational tool.

Researchers have shown how preschool teaching methods differ from others:

1. In contrast, preschoolers learn from each other during communication. However, schoolchildren learn from books.

2. Kindergarten children need to be taught in a live game where everything is taught: the educator, the toys, the songs, and the children's community. Children in school learn using explanations, reading, and conversations (games are no exception, especially for young children!).

3. Avoid long classes in kindergarten and encourage children more by praising them. Children in schools can already endure 45 minutes (with younger ones you can take small breaks during class) and the main encouragement for them is the grades.

During our research study, we have found out endless lectures and speeches quenched children's interest and, conversely, additional materials: video lessons for children were interesting not only for preschoolers but also for school-age children. Video as the development of games. The method of teaching English to preschool children sometimes makes parents think: - why is it taught to us differently ..? Indeed, the method of teaching English to preschool children (7-8 years) depends on their age characteristics, and adults sometimes do not think about it. They remember how they learned a foreign language in adulthood. And that's a whole different age group and different teaching methods.

The main difference between adults is that children do not learn English, they play it. Forcing something at this age is useless. Visual-figurative thinking predominates in preschool children. Children think in pictures and this allows them to use English as much as possible so that children don't feel the need for translation. It is enough to connect the word with a picture-toy, an object, a gesture that corresponds to its image. Thus, such a popular method for teaching preschool children and young learners is a method of full physical response. It is a way of learning new words or phrases in which each word, along with the phrase, is invented by the sign and learns to imitate them. For example, children's imaginations are active, and with the word apple, 
(ISSN - 2752-7018)

VOLUME 02 ISSUE 01 Pages: 69-78

SJIF IMPACT FACTOR (2021: 5 · 376)

OCLC - 1276789625 METADATA IF - 7.569

children seem to bite an imaginary apple, repeating the gesture.

Experts prove that grammar rules are not important in teaching English to children in preschool institutions. Young children also learn grammar differently. Logical thinking only begins to take shape closer to school, and develops more or less in a teenager's thinking. Accordingly, teaching a foreign language to preschoolers and primary school students is not based on explaining the rules (the rules are abstract, they make it difficult for children). It is useless to explain to a small child the meaning of the verb to be "to be, to appear."

Therefore, most children at 7-8 age can use the forms perfectly, for example: I / you / he/... etc. without any idea about the forms of the verb "to be". They learn grammatical features as they grow up. Since abstract-logical thinking is not developed in preschool children and it is still in the formative stage in younger students, it is not always necessary to draw parallels with the mother tongue. Early start of training allows you to form a foreign language separately from your native language. Adults (the student's parents, as well as grandparents) are often unaware of this feature of teaching methods, so sometimes funny situations occur when a child starts asking at home: "What is it in English ...? What happens in English. ..? "Most children answer the questions. However, sometimes a child in such a situation becomes confused and silent in response. They understand their educator. The educator uses picture cards or toys and shows the child what it is and asks the child all? Principally, child knows what an "apple" would be in his native language and English, but these two languages exist separately in his/her head and still cannot draw parallels between them.

Vise verse, parents sometimes complain that a preschooler or first-grade pupil can describe a picture in English, he chooses the sentence correctly in the exercises in the picture, but does not translate. If he describes and chooses correctly, it means he understands what he is talking about and not translating into his native language means that his language is naturally formed and in the future. if the lessons are structured correctly, the child will not translate from native to English but immediately make a statement in English. It is advisable to change the frequency of activities in teaching English to children in preschool institutions. 
(ISSN - 2752-7018)

VOLUME 02 ISSUE 01 Pages: 69-78

SJIF IMPACT FACTOR (2021: 5 · 376)

OCLC - 1276789625 METADATA IF - 7.569

\section{Conclusion}

In conclusion, we can say that one of the features of teaching English to preschool children is that children do not just sit at a desk and turn the pages of books and notebooks. This process should not be boring so that the children should strive for knowledge on their own. Children think clearly, take everything literally, say simple sentences ... If an educator explains something, he or she must give an example. Games in English should be played with preschoolers in order to achieve positive results and form a positive attitude towards the foreign language in the child. The methods of learning should be able to cultivate an interest in the topic, develop the child's communication skills, and express themselves, rather than mastering as many lexical units as possible.

\section{REFERENCES}

1. Rakhmanov I.V. (1980). Teaching oral speech in a foreign language / I.V. Rakhmanov. M.: Higher school, p.120; Makhkamova G.T. (2004). Formation of skills and abilities of oral foreign language speech in preschoolers (5-6) years: Dissertation of Candidate of Pedagogical
Sciences /T., p. 238; Kadyrova F.R. (2010). Problems of language education in preschool institutions of the Republic of Uzbekistan: Education, pp.12 - 15; Tsetlin B.C. (1970). Control of speech skills in teaching foreign languages. M., p. 119; Jalolov J. (1996). Foreign language teaching methodology. Tashkent. p. 368. Sattarov T.K. (2000). Formation of professional skills of the future teacher of a foreign language in practical classes in the specialty (on the material of the English language): Abstract of the PhD Thesis - T. p.32;

2. Makhkamova G.T. (2004). Formation of skills and abilities of oral foreign language speech in preschoolers (5-6) years: Dissertation of Candidate of Pedagogical Sciences / T., p. 238;

3. Kadyrova F.R. (2010). Problems of language education in preschool institutions of the Republic of Uzbekistan: Education, pp.12 - 15;

4. Achkasova N.N. (1997). Methodology for constructing a propaedeutic course in English for children aged 5 years on a musical basis (on the basis of a children's opera) - Dissertation of Candidate of Pedagogical Sciences / M; Osiyanova O.M. (1993). National-cultural component of the content of teaching English in elementary school. Moscow; Malkina, N. A. (1996). Methods of using fairy tales in teaching 
(ISSN - 2752-7018)

VOLUME 02 ISSUE 01 Pages: 69-78

SJIF IMPACT FACTOR (2021: 5. 376)

OCLC - 1276789625 METADATA IF -7.569

Publisher: Frontline Journals

preschool children oral speech in English: Abstract of the PhD thesis. p.16; Denisenko O.A. (1995). Methods of early teaching of English based on the works of children's English literature: PhD Thesis. - p.206;

5. Yatsenko I.A. (1994). Ways of methodological integration of speech development and foreign language teaching in kindergarten. - M: Dissertation of Candidate of Pedagogical Sciences /p.186

6. Negnevitskaya E. I. (1987). Foreign language for the smallest: yesterday, today, tomorrow // Foreign languages at school. (6) 20-26.

7. Kolieva N.F. (1967). Features of teaching English to preschool children: Dissertation of Candidate of Pedagogical Sciences / p.184; Grigoryeva V.V. (1988). On the formation of foreign language speech activity of preschool children: Dissertation of Candidate of Pedagogical Sciences / p. 224.

8. Dolnikova R.A., Fribus L.G. (2008). How do we teach children to speak English. Teaching children from 4 to 7 years old. A guide for teachers and parents. Sankt-Peterburg: Karo. p.176

9. Futerman Z.A. (1984). Foreign language in kindergarten: questions of theory and practice. - Kiev: Science. p. 144
10. Ponimatko A.P. (1992). Teaching preschoolers a foreign language based on game modeling of foreign language communication: Dissertation of Candidate of Pedagogical Sciences / A.P. Ponimatko. - K. p.24

11. Denisenko O.A. (1995). Methods of early teaching of English based on the works of children's English literature: Dissertation of Candidate of Pedagogical Sciences /p. 206

12. Rybakova N.V. (1995). Teaching communication on a plot-situational basis for students of the 1st grade of secondary school: Ph.D. Thesis. p. 186

13. Malkina, N. A. (1996). Methods of using fairy tales in teaching oral speech in English to preschoolers: Abstract of the Dissertation of Candidate of Pedagogical Sciences / SPb., p.16

14. Leontiev A.A. (1986). Early learning of a foreign language / / Russian language abroad. (5) 50-53; Kostomarov V.G. (1965). Colloquial speech: definition and role in teaching // Russian language in the national school (31)10-19.

15. Sholpo I. L. (1999). How to teach a preschooler to speak English: textbook. Manual on the methodology of teaching English for pedagogical universities, colleges and schools 
FRONTLINE SOCIAL SCIENCES AND HISTORY JOURNAL

(ISSN - 2752-7018)

VOLUME 02 ISSUE 01 Pages: 69-78

SJIF IMPACT FACTOR (2021: 5 • 376)

OCLC -1276789625 METADATA IF -7.569

Crossref doi 81 Google

\%

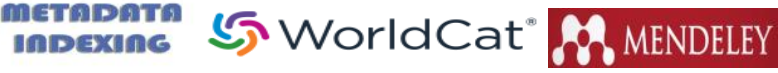

Publisher: Frontline Journals

in the specialty Foreign Language Teacher in

Kindergarten. - St. Petersburg: p. 155

16. Futerman Z.A. (1984). Foreign language in kindergarten: questions of theory and practice.

- Kiev: p. 144

17. Arkin E. A. (1968). Child in preschool years. M., p.175

18. Ushinsky K.D. (1950). Thinking and Speech: Collected Works. T. 10.-M: p.668

19. Vygotsky L.S. (1999). Thinking and speech. M.: Labyrinth, p. 352

20.Zimnyaya I.A. (2001). Psychology of teaching foreign languages at school. - M.: Enlightenment, p. 228

21. Bonk N. A. (1997). English for kids. - M.: Publishing house Ruchenkina, p.171

22. Vygotsky L.S. (1967). Imagination and creativity in childhood. - M.: Pedagogy, p. 92; Zaporozhets A.V. (1948). Psychology of the perception of a fairy tale by a preschool child / / Children's education (9) 34-41; Mukhina V.S. (1999). Developmental psychology: phenomenology of development, childhood, adolescence - $\mathrm{M} \quad .$. Publishing Center "Academy" pp. 37-38; Usova A.P. (1981). Education in kindergarten / ed. valid member APN of the USSR A. V. Zaporozhets. - 3rd ed., Rev. - M. : Education, p.175.
23. Mukhina V.S. (1999). Developmental psychology: phenomenology of development, childhood, adolescence - M .: Publishing Center "Academy" pp. 37-38 